Cahiers « Mondes anciens »

ANCIENS

Histoire et anthropologie des mondes anciens

$13 \mid 2020$

Qu'est-ce que faire école ? Regards sur « l'école de

Paris »

\title{
Ischia and After
}

Ischia et ses suites

\section{Anthony Snodgrass}

\section{(2) OpenEdition \\ 1 Journals}

Electronic version

URL: http://journals.openedition.org/mondesanciens/2801

DOI: 10.4000/mondesanciens. 2801

ISSN: 2107-0199

Publisher

UMR 8210 Anthropologie et Histoire des Mondes Antiques

\section{Electronic reference}

Anthony Snodgrass, "Ischia and After », Cahiers " Mondes anciens » [Online], 13 | 2020, Online since 10 June 2020, connection on 12 June 2020. URL : http://journals.openedition.org/mondesanciens/2801 ; DOI : https://doi.org/10.4000/mondesanciens.2801

This text was automatically generated on 12 June 2020 .

\section{(c) (†) $\ominus$}

Les Cahiers «Mondes Anciens » sont mis à disposition selon les termes de la licence Creative Commons Attribution - Pas d'Utilisation Commerciale - Pas de Modification 4.0 International. 


\title{
Ischia and After
}

\author{
Ischia et ses suites
}

\section{Anthony Snodgrass}

1 For me, it all began at Ischia in 1977 - the colloquium on "Idéologie funéraire". ${ }^{1}$ I still do not know how I came to be invited. It was of course a joint Franco-Italian event and my contacts with the organisers, tenuous as they were, were closer on the Italian side: as a colleague of David Ridgway in Edinburgh, I knew Bruno D'Agostino and Patrizia Gastaldi and had been in indirect touch with Giorgio Buchner. On the French side, there were certainly awe-inspiring names, some of them people who were later to become real friends - Pierre Vidal-Naquet, Alain and Annie Schnapp, François Hartog - but as yet I can have been, at most, a name to them. At that time, I had been in Cambridge for less than a year and the work of the Centre, as we all called it, had become rapidly more familiar to me, partly through the influence of Moses Finley and the fact that François de Polignac was spending a term studying with him in Cambridge; partly through that of other colleagues with Parisian connections - Geoffrey Lloyd, Dick Whittaker - and also Richard Gordon, a very frequent visitor to Cambridge. What I had not yet detected was any connection between the work of the Centre and archaeology.

2 In hindsight, I see that the Ischia Colloquium marked the establishment, undoubtedly intentional, of just that connection. The choice of funerary ideology as a topic demanded archaeological participation, and in the event archaeology was almost to predominate. But present, too, was Jean-Pierre Vernant: after I had heard his paper and he mine, I recall his joining a small group of us in discussion: "Qui est ce vieux farfelu...?" were the words that he - mischievously - put in my mouth as I greeted him for the first time, to laughter that drowned my protesting denials. It was in fact mainly his contributions in discussion that led me to modify my view of the agency behind the much later cults set up at Bronze Age tombs: his words "La cité, c'est tout !" still sound in my ears today. There too was Claude Bérard from Lausanne, whom I knew as an archaeologist but who was so much more besides.

3 Each day of the proceedings at Ischia widened my horizons, not least the memorable final presentation by Denys Lombard of ceremonial cremations on Bali and Sulawesi. Yet I believe that, for me at least, the perception of the Centre as the hub of an "École" 
came afterwards. It was only on subsequent visits to Paris that I came to know, among many others, Claude Mossé and Marcel Detienne, to see how large the group had grown and how closely the work of all of them hung together. Hitherto I had known little or nothing of the work of Louis Gernet or Ignace Meyerson, to which they now introduced me. It came as no surprise when, about this time, I began to hear references to the 'Paris School' as the most interesting movement in world-wide Classical studies: it was so obviously true.

4 A striking sequel to the Ischia conference was that the resultant volume was jointly published, for the Anglophone world but with a text entirely in French and Italian, by the Cambridge University Press in 1982. This unconventional move, if not the very first such venture in the history of the Press, was an exceptionally rare one; at the same time, it was a tribute to the perceived importance of the volume and a testimony to the growing international influence of the group behind it. That influence has not faded, as is shown by the list of contributors to this issue: it contains a few scholars whom I would call contemporaries, but I am delighted to see, as well, names of people whom I know to be of less than half my own age. It is clear that the expression "the Paris School" still has much life in it. As the sole Anglophone participant at Ischia, I depended heavily (for the first but by no means the last time) on the skills of Annie Schnapp-Gourbeillon as translator of my text; today, the multi-lingual and multinational network of the École reaches even beyond the far-flung branch offices of the Cambridge University Press, in America and the Antipodes, from which that publication of 1982 was issued.

5 More than a decade later, a cordial post-card of good wishes arrived, this time from Capri rather than Ischia, signed by Bruno D'Agostino, Alain Schnapp, Jean-Pierre Vernant, Claude Bérard, François Lissarrague and Oswyn Murray, to re-awaken the memories of my first encounter with the "École de Paris." That was something that I still look back on as an unearned privilege.

\section{NOTES}

1. Gnoli G. and Vernant J.-P. eds, La mort, les morts dans les sociétés anciennes, Cambridge, 1982. 


\section{ABSTRACTS}

This short note reminds the important role the meeting "La mort, les morts dans les sociétés anciennes", which took place in Ischia in 1977, played to establish a long-lasting connection between historical anthropology and classical archaeology.

Dans cette note, l'auteur rappelle le rôle important que joua le colloque « La mort, les morts dans les sociétés anciennes ", qui se tint à Ischia en 1977, dans le rapprochement entre anthropologie historique et archéologie classique.

INDEX

Keywords: historical anthropology, classical archaeology, classical studies

Mots-clés: anthropologie historique, archéologie classique, études classiques

\section{AUTHOR}

\section{ANTHONY SNODGRASS}

University of Cambridge 